\title{
Settlement of Multiple Certificate Disputes On The Same Land Object
}

\author{
Rica Intan Febriyanti \\ Faculty of Law, University Surabaya \\ E-mail: ricaintan@gmail.com
}

\begin{abstract}
Land has an economic aspect with the value of the rupiah increasing every year, in the form of an increase in NJOP on SPPT PBB. Regarding legal land ownership through the inclusion of the owner's name on the land title certificate, several court decisions have found cases of double certificates which are original and authentic certificates. To determine who is entitled to the ownership of land rights in the same object, a lawsuit is made through the district court with the land office as a co-defendant. The purpose of this study is a legal remedy in the event of a land dispute due to dual certificates and the validity of the issuance of multiple certificates whose legality will be recognized according to law. This study uses empirical juridical methods, namely juridical research conducted by examining library materials called library research with a statute approach. Sources of Legal Materials used in this legal research use primary legal materials which are authoritative legal materials, meaning they have authority. The results of this study are the certificates issued by the land agency are valid until they are declared null and void by the district court, on the validity of the dual certificates, the applicable certificate is the land certificate which was issued earlier and declared valid by the panel of judges. Suggestions from this research are that the land office is expected to be more careful in conducting research on physical and juridical data in issuing land rights certificates.
\end{abstract}

Keywords: Multiple Certificates, Land Office, Land Rights

\section{INTRODUCTION}

Land is one of the natural resources that is useful and has enormous usability for human survival. Land is a source of livelihood and livelihood for the community and even land cannot be separated from the birth of a human until the human dies . Land is valued as one of the high-value and special assets that encourages everyone to own it. Land is one of the absolute human needs, meaning that human life is influenced and determined by the existence of land (J. Andi Hartanto: 2014). In national law relating to land law, land law must be in line with the constitution in force in Indonesia, which as Article 33 paragraph (3) of the 1945 Constitution, with the formulation that "Earth, water and natural resources contained therein, whose control is assigned to the State of the Republic of Indonesia, must be used for the greatest prosperity of the people." These provisions are the legal basis for national land politics which have one goal, namely for the prosperity of the people, which is used by the state control mechanism which is then further elaborated, among others in Article 2 paragraph (2) of Law Number 5 of 1960 concerning Basic Regulations. Agrarian Principles. Where the state has the power to regulate land that has been owned by a person or legal entity or free land that has not been owned by a person or legal entity will be directly controlled by the state. (Elza Syarief: 2012). 
Land has a very important function for the community and for many people who do everything they can to obtain land rights, some even take land belonging to other people. The condition of the community has resulted in agrarian problems and disputes in social life. In connection with the foregoing, in order to minimize the incidents mentioned above, it is necessary to provide legal certainty of land ownership rights (Lestari, 2014). To obtain legal certainty and certainty of land rights, the community needs to register the land they own to obtain a land title certificate, where this land title certificate serves as a strong proof of ownership of the land rights they have. Land rights certificates are valid as strong evidence as regulated in the Basic Agrarian Law in Article 32 paragraph (1) Government Regulation Number 10 of 1961 concerning land registration, which has now been revoked and reaffirmed in Government Regulation Number 24 of 1961. 1997. Certificate is a strong and authentic evidence. Certificates are a form of embodiment of legal certainty guarantees for certificate holders as perfect evidence as long as the opposing party cannot prove otherwise.

This dual certificate dispute arises because of objections from the owner of the same certificate in one object of land rights and both certificates are valid and authentic. The case regarding the double certificate is found in Cassation Decision No. 976 K/PDT/2015 with liem teddy as the applicant for cassation against the Ministry of Defense and Security/Armed Forces of the Republic of Indonesia cq. Indonesian National Army - Army Regional Military Command III/Siliwangi as the respondent of the cassation.

As for the case, on October 5, 2006 the Plaintiff purchased a plot of land and a building located on Jl. Cicendo Number 16 (formerly Number 20) Babakan Ciamis Village, Sumur Bandung District, Bandung City, from PT. Propelling based on the Sale and Purchase Deed Number 158/2006 which was made before the Land Deed Making Officer (PPAT) Tien Norman Lubis, SH, PPAT Bandung City. Whereas, the land has been certified with Hak Guna Bangunan Number 46/Kelurahan Babakan Ciamis, Situation Figure Number 835/1993 dated February 11, 1993, with an area of $484 \mathrm{~m}^{2}$ on behalf of Co-Defendant I, which was issued by the National Land Agency of Bandung City and has been reversed from as the seller to the applicant for the cassation as the buyer. That, when the land was purchased by the Plaintiff, the object of the sale was the Building Use Rights Certificate Number 46/Kelurahan Babakan Ciamis, Situation Picture Number 835/1993 dated 11 February 1993, the area of $484 \mathrm{~m}^{2}$ issued by the Bandung City National Land Agency was issued on 07 August 1993 the rights are still valid until July 21, 2013.

Whereas, when the land was purchased by the Plaintiff in 2006 the condition of the land and building was empty and controlled, and cared for by the Plaintiff until now, when the Plaintiff carried out renovations on the building by first obtaining a building permit Number 503.648.1/1314/DISTARCIP /VII/2008 on behalf of the Plaintiff, as well as permission from the 
This work is licensed under a Creative Commons Attribution-ShareAlike 4.0 International License

relevant agency, with the intention of being leased to a Government Sharia Bank, the Plaintiff was visited by Defendant I with letter Number B/831/XI/2008 dated November 6, 2008 which basically stated that regarding status of land and buildings on Jl. Cicendo Number 16 (formerly Number 20), the City of Bandung is an asset of the TNI AD KODAM III/SLW in accordance with the Right of Use Certificate Number 18 dated August 28, 1998, which ordered the Plaintiff to vacate the land and building (in casu land on Jl. Cicendo Number 16 ( formerly Number 20) belonging to the TNI AD KODAM III/SLW no later than November 30, 2008. Whereas, prior to the sale and purchase process, formal data checks were carried out through the Bandung City National Land Agency/Bandung Land Office, and also due to the transfer of assets from PT Propelat, then the announcement was made through the People's Thoughts Newspaper 2 times, and there were no objections from any party including Defendant I, and the process of changing the name of the Building Use Rights Certificate Number 46/Kelurahan Babakan Ciamis was carried out by the Bandung Land Office without notifying that the above The Plaintiff's Certificate has been issued a Right of Use Certificate Number 18/Kel. Babakan Ciamis on behalf of the Siliwangi Military Command. It is clear that multiple certificates have been issued but there are differences in the granting of land rights to the same object. Both parties have good intentions for the ownership of the land. This case will be the basis for making legal research with the title Settlement of Disputes on Multiple Certificates of the Same Land Object.

\section{RESEARCH METHODS}

Legal research is a process to find the rule of law, legal principles, and legal doctrine in order to answer the legal issues faced. This is in accordance with the character of legal science. There are two types of legal research proposed, namely normative legal research and empirical legal research. The type of research used in this research is normative legal research, which is a research that mainly examines positive legal provisions and legal principles. To support legal research, research methods are used which consist of the approaches used in this legal research, namely the statute approach, the case approach, the comparative approach and the conceptual approach. This study uses empirical juridical methods, namely juridical research conducted by examining library materials called library research with a statute approach. Sources of Legal Materials used in this legal research use primary legal materials which are authoritative legal materials, meaning they have authority. Primary legal materials consist of legislation and judges' decisions. The primary legal materials in this study are:

1. Basic Agrarian Law No. 5 of 1960

2. Regulation of the Head of the National Land Agency No. 1 of 1999 concerning Procedures for Handling Land Disputes 
3. Government Regulation No. 24 of 1997 concerning Land Registration

4. Law -Law Number 2 of 1986 concerning General Courts and its amendments.

While secondary legal materials are all publications on law that are not official documents. Publications on law that are used as secondary legal materials in research are textbooks, legal dictionaries, literatures, scientific journals, and other dictionaries as support.

\section{RESULT AND DISCUSSION}

\section{Land Registration and Certificate Issuance According to Legislation}

Land registration according to Boedi Harsono is a series of activities carried out by the government continuously and regularly, in the form of collecting certain information or data, processing, storing and presenting it for the benefit of the people, in order to guarantee legal certainty in the land sector, including the issuance of evidence and its maintenance (Boedi Harsono: 2007).

Land registration is regulated in Article 1 Paragraph (1) Government Regulation Number 24 of 1997. Land registration is an activity carried out by the government regarding the collection, processing, bookkeeping, presentation and maintenance of physical data and juridical data in the form of maps and lists of land parcels and land parcels. apartment unit, including the provision of proof of title for a parcel of land that already has rights and ownership rights to an apartment as well as certain rights that encumber it. The government carries out land registration activities continuously and continuously. The plot of land in question is part of the earth's surface which is a limited area (Jayadi Setiabudi: 2012). In Article 9 of Government Regulation no. 24 of 1997 regulates the object of land registration including.

a. Plots of land owned with Ownership Rights, Cultivation Rights, Building Use Rights and Use Rights;

b. Management Rights Land;

c. Waqf Land;

d. Ownership of Flat Units;

e. Mortgage right ;

f. State Land;

Land registration is one of the requirements in an effort to organize and regulate the allocation, ownership, control and use of land, including to overcome various land problems. Land registration also provides certainty of rights to rights holders as well as legal protection with evidence in the form of land certificates, as a structuring of land control and ownership as well as land use. The spearhead of land registration is the issuance of certificates that produce physical data and juridical data regarding the rights to the land. 
This work is licensed under a Creative Commons Attribution-ShareAlike 4.0 International License

Legal Efforts If a Land Dispute Occurs Due to Dual Certificates and the Validity of the Issuance of Multiple Certificates whose Legality will be Recognized according to Law

Disputes are conflicts, disputes, or disputes that occur between one party and another and or between one party and various parties related to something of value, whether in the form of money or objects (Salim HS: 2012). The definition of land disputes is also explained in Article 1 of the Regulation of the Head of the National Land Agency Number 1 of 1999, namely differences of opinion between interested parties regarding the validity of a right, granting land rights, land registration, including the transfer and control of evidence and parties who have rights. interests and have legal relationships with other parties who are affected by the status of the land (Rusmadi Murad: 1991).

As for the case, on October 5, 2006 the Plaintiff purchased a plot of land and a building located on Jl. Cicendo Number 16 (formerly Number 20) Babakan Ciamis Village, Sumur Bandung District, Bandung City, from PT. Propelling based on the Sale and Purchase Deed Number 158/2006 which was made before the Land Deed Making Officer (PPAT) Tien Norman Lubis, SH, PPAT Bandung City. Whereas, the land has been certified with Hak Guna Bangunan Number 46/Kelurahan Babakan Ciamis, Situation Figure Number 835/1993 dated February 11, 1993, with an area of $484 \mathrm{~m}^{2}$ on behalf of Co-Defendant I, which was issued by the National Land Agency of Bandung City and has been reversed from as the seller to the applicant for the cassation as the buyer. That, when the land was purchased by the Plaintiff, the object of the sale was the Building Use Rights Certificate Number 46/Kelurahan Babakan Ciamis, Situation Picture Number 835/1993 dated 11 February 1993, the area of $484 \mathrm{~m}^{2}$ issued by the Bandung City National Land Agency was issued on 07 August 1993 the rights are still valid until July 21, 2013.

Whereas, when the land was purchased by the Plaintiff in 2006 the condition of the land and building was empty and controlled, and cared for by the Plaintiff until now, when the Plaintiff carried out renovations on the building by first obtaining a building permit Number 503.648.1/1314/DISTARCIP /VII/2008 on behalf of the Plaintiff, as well as permission from the relevant agency, with the intention of being leased to a Government Sharia Bank, the Plaintiff was visited by Defendant I with letter Number B/831/XI/2008 dated November 6, 2008 which basically stated that regarding status of land and buildings on Jl. Cicendo Number 16 (formerly Number 20), the City of Bandung is an asset of the TNI AD KODAM III/SLW in accordance with the Right of Use Certificate Number 18 dated August 28, 1998, which ordered the Plaintiff to vacate the land and building (in casu land on Jl. Cicendo Number 16 ( formerly Number 20) belonging to the TNI AD KODAM III/SLW no later than November 30, 2008. Whereas, prior to the sale and purchase process, formal data checks were carried out through the Bandung City National Land Agency/Bandung Land Office, and also due to the transfer of assets from PT Propelat, then the 
This work is licensed under a Creative Commons Attribution-ShareAlike 4.0 International License

announcement was made through the People's Thoughts Newspaper 2 times, and there were no objections from any party including Defendant I, and the process of changing the name of the Building Use Rights Certificate Number 46/Kelurahan Babakan Ciamis was carried out by the Bandung Land Office without notifying that the above The Plaintiff's Certificate has been issued a Right of Use Certificate Number 18/Kel. Babakan Ciamis on behalf of the Siliwangi Military Command.

After the Plaintiff was visited by Defendant I and given letter Number B/831/XI/0 dated November 6, 2008, Defendant I ordered the Plaintiff to vacate the a-quo land and building without going through the applicable legal process, the Plaintiff checked with the City National Land Agency. Bandung (in casu the Bandung Land Office) with a letter dated November 25, 2008 to inquire about the status of the Plaintiff's land, but the efforts made by the Bandung Land Office in mediating the Plaintiff with Defendant I and with Co-Defendant I have not been reached, and no agreement has been reached until now. this. Whereas, as was the case when on September 30, 2011, the Plaintiff submitted a request for a change in the Right to Build into a Hak Milik to the Bandung City National Land Agency, and the Bandung Land Office responded with a letter dated October 18, 2011 which basically acknowledged by the Bandung Land Office that Building Use Rights Certificate Number 46/Kelurahan Babakan Ciamis, Situation Picture Number 835/1993 dated February 11, 1993, area of $484 \mathrm{~m}^{2}$ issued by the National Land Agency of Bandung City (in casu. Bandung Land Office), published on August 7, 1993. the name of the Plaintiff, but there is a note on the land that a Right of Use Certificate Number 18/Kelurahan Babakan Ciamis has been issued in the name of KODAM HI Siliwangi (in casu Defendant I ), and the Bandung Land Office said that the process of changing HGB to Property Rights so that the Plaintiffs resolve the problem first first with the KODAM Ill Siliwangi (in casu the Defendant I).

Whereas, the actions of the Bandung Land Office which did not want to carry out the process of increasing the Plaintiff's Building Use Rights into Ownership Rights, resulted in losses and no legal certainty for the Plaintiffs, after the Certificate of Building Use Rights Number 46/Babakan Ciamis expired on July 21, 2013 , therefore there is sufficient legal ground for the Plaintiff to be declared the legal owner of the land and buildings.

Whereas against the lawsuit the Bandung District Court has given its Decision Number 336/Pdt.G/2013/PN.Bdg. dated May 19, 2014 which is as follows:

1. Reject the Plaintiff's provisional claim

2. Accept the Plaintiff's Defendant's claim in part;

3. To declare that Defendant I and the Bandung Land Office have committed an unlawful act (Onrecht Matigeedad); 
This work is licensed under a Creative Commons Attribution-ShareAlike 4.0 International License

4. Declaring valid and binding Deed of Sale and Purchase No. 158/2006 dated October 5, 2006 drawn up before the Land Deed Making Officer, Tien Norman Lubis, SH, PPAT Bandung City in conjunction with Building Use Rights Certificate Number 46/Kelurahan Babakan Ciamis, picture of situation dated 11-02-1993 Number 835/1993 area $484 \mathrm{~m}^{2}$ written in the name of Liem Teddy.

5. Stating that the Plaintiff is the legal owner of a plot of land and building located on Jl. Cicendo Number 16 (formerly Number 20), the City of Bandung based on the Certificate of Building Use Rights Number 46/Kelurahan Babakan Ciamis, picture of the situation dated 11-02-1993 Number 835/1993 with an area of $484 \mathrm{~m}^{2}$ written in the name of Liem Teddy (in casu. Plaintiff);

6. Punish Co-Defendant I and Co-Defendant Bandung Land Office to submit and obey this decision.

Considering, whereas at the level of appeal against the Bandung Land Office's application, the District Court's decision has been annulled by the Bandung High Court with Decision Number 399/PDT/2014/PT.BDG dated November 11, 2014 which is as follows:

1. Received the appeal from the Appellant/ the Plaintiff in the original Reconvention of Defendant I;

2. Canceling the decision of the Bandung District Court Number 336/Pdt.G/2013/PN.Bdg dated May 19, 2014 for which the appeal was requested;

3. Granted the Plaintiff's claim in the Convention/Defendant I in the Convention in part

4. To declare that the Deed of Sale and Purchase Number 54 dated 12 May 1959 is valid according to law;

5. Declaring that it is legal according to the Right of Use Certificate Number 18 dated 11 November 1998, Measurement Letter Number 13/Babakan Ciamis/1998 dated 29 August 1998, covering an area of $464 \mathrm{~m}^{2}$ on behalf of the Ministry of Defense and Security/Armed Forces of the Republic of Indonesia/Indonesian National Army-Force Land/Military Regional Command III/Siliwangi;

6. Stating that the object of dispute on Jalan Cicendo Number 18 A now Number 20 Bandung Certificate of Use of Land Rights Number 18 dated 11 November 1998, Measurement Letter Number 13/Babakan Ciamis/1998 dated 29 August 1998, covering an area of 464 $\mathrm{m} 2$ belongs to and assets of the Ministry of Defense and Security /Republican Armed Forces/Indonesian National Army-Army/Regional Military Command III/Siliwangi;

7. To punish the Defendant in the Convention/Plaintiff in the Convention to vacate and submit the object of dispute to the Plaintiff in the Convention/Defendant $I$ in the Convention on the land and building of the object of the dispute; 
8. To declare Deed of Sale and Purchase Number 158/2006 dated October 5, 2006 and Certificate of Building Use Rights Number 46/Kelurahan Babakan Ciamis, Picture of Situation dated February 11, 1993 Number 835/1993, area of $484 \mathrm{~m} 2$ written on behalf of Liem Teddy (ic. Plaintiff) has no legal force;

Whereas in assessing the validity of one of the 2 (two) authentic evidence of rights, the rule applies that the certificate of rights issued earlier is valid and has legal force. Whereas in accordance with the facts of the trial, the Building Use Rights Certificate (HGB) Number 1458 which was later extended by the HGB Certificate Number 46 on behalf of Co-Defendant I (PT. Propelat) is proof of rights which was issued earlier on February 11, 1993 than the Land Use Rights Certificate Number 18 which published on November 11, 1998. Whereas the HGB Certificate Number 46 has been sold by Co-Defendant I to the Plaintiff/Applicant for Cassation in front of PPAT so that it is true that the Plaintiff/Applicant for Cassation is the legal owner of the object.

That from the legal facts above, the applicant for the cassation purchased the land in good faith and in accordance with the terms of the sale and purchase agreement which was regulated in accordance with the procedures in the PP. The registration of the land and the land was traded through PPAT until the issuance of a certificate which was a form of juridical submission of the transfer of land rights. . On the other hand, the Land Office issues certificates of other rights for the Siliwangi Kodam, in this case both valid and authentic certificates. The Supreme Court is of the opinion that there are sufficient reasons to grant the Cassation Petitioner LIEM TEDDY and cancel the Bandung High Court Decision Number 399/Pdt/2014/PT.BDg. dated November 11, 2014 which annulled the Decision of the Bandung District Court Number 336/Pdt.G/2013/PN.Bdg. dated May 19, 2014. The Supreme Court gave the following decisions:

1. Granted the petition for cassation from the Petitioner for Cassation, LIEM TEDDY;

2. Canceling the decision of the Bandung High Court Number 399/Pdt/2014/PT.BDg. dated November 11, 2014 which annulled the Decision of the Bandung District Court Number 336/Pdt.G/2013/PN.Bdg. May 19, 2014;

In its legal considerations, the panel of judges is of the opinion that in assessing the validity of one of the 2 (two) authentic evidence of rights, the legal rule applies that the certificate of rights issued earlier is valid and has legal force. The legal consequence in this case is that the certificate that arises after the previous certificate has been issued with the name of a different right owner, then based on a court decision, the certificate issued afterwards is null and void and must be crossed out in the land book. So the second certificate holder is not entitled to own the object of the land rights and is obliged to return the certificate to the national land agency so that it is not 
This work is licensed under a Creative Commons Attribution-ShareAlike 4.0 International License

misused. The case of the dual certificates made the national land agency to be more careful with the issuance of land rights certificates so that they would no longer make mistakes.

\section{CONCLUSION}

Land registration is the spearhead of the Basic Agrarian Law, through land registration, legal certainty will be obtained regarding physical data and juridical data from a land. Land registration continues to be carried out by the Government with the assistance of PPAT and other parties. Land that has been registered will become a new right in accordance with the LoGA and a certificate will be issued as strong and complete evidence.

Agrarian disputes cannot be denied and it is the duty of BPN to correct data on land. Land disputes can be in the form of multiple certificates that have been issued by the land office and both certificates are valid and authentic certificates. the validity of one of the 2 (two) authentic evidence of rights, then the legal rule applies that the certificate of rights issued earlier is valid and has legal force.

\section{SUGGESTIONS}

It is advisable for the old right holder to immediately take care of the old right he has into the new right which is stated in the certificate issued by the local Land Office. PPAT who will assist the land registration process should check and attach the original certificate

To protect the interests of the seller and buyer in transferring land rights, PPAT should request a letter stating that the land being traded is not a regional or state asset from the local government agency. It is expected that BPN will exercise caution in issuing certificates, especially in issuing certificates for government agencies.

\section{REFERENCES}

Harsono, Boedi (2007), Indonesian Agrarian Law, History of the Formation of Basic Agrarian Laws, Content and Implementation, Jakarta: Djambatan

J. Andi Hartanto (2014), Land Law Characteristics of Sale and Purchase of Land whose Land Rights have not been registered, Surabaya : Laksbang Justitia.

Lestari, S. E. (2014). Penyelesaian Sengketa Kewenangan Antar Lembaga Negara oleh Mahkamah Konstitusi. DiH: Jurnal Ilmu Hukum, 10(19).

Murad, Rusmadi (1991), Legal Dispute Resolution on Land, Bandung : Alumni Publisher.

Salim (2012), Mining Dispute Settlement Law in Indonesia, Mataram:Reka Cipta Pustaka. 
This work is licensed under a Creative Commons Attribution-ShareAlike 4.0 International License

Setiabudi, Jayadi (2012), Procedures for Managing Home Land and All Permits, Jakarta: Jagakarsa.

Syarief, Elza (2012), Resolving Land Disputes, Jakarta: Gramedia. 